\title{
A Current Method in Gynecological Cancer Prediction: "Micronucleus": Review
}

\author{
Jinekolojik Kanser Öngörüsünde \\ Güncel Bir Metod: "Mikronükleus"
}

\section{Ayla AÇAR ESER, ${ }^{a}$ \\ Neslihan GÜRBÜZ, ${ }^{\text {, }}$ \\ ikbal KAYGUSUZ, \\ Metin CANBAL, ${ }^{c}$ \\ Aydın KÖŞÜŞ, ${ }^{a}$ \\ Nermin KÖşÜŞ̧a}

${ }^{a}$ Department of Gynecology and Obstetrics, 'Department of Family Medicine, Turgut Özal University Faculty of Medicine, bLaboratory of Animal Breeding and Experimental Research Center, Gazi University Faculty of Medicine, Ankara

Geliş Tarihi/Received: 17.08 .2014 Kabul Tarihi/Accepted: 05.11.2014

Yazışma Adresi/Correspondence: Ayla AÇAR ESER

Turgut Özal University Faculty of Medicine, Department of Gynecology and Obstetrics, Ankara,

TÜRKIYE/TURKEY

aylaacar76@yahoo.com.tr

\begin{abstract}
Prediction and early diagnosis of cancer are vital in gynecology. Studies have shown that both micronucleus (MN) and micronucleus tests (MNT)s can be used to predict cancers. Approximately $92 \%$ of all of the human malignancies occur in epithelial tissues. The MN assay in exfoliated cells is an innovative genotoxicity technique which holds promise for the study of epithelial carcinogens. Micronuclei are usually produced during the metaphase/anaphase transition of mitosis. If the process of cell division is disturbed, the sharing of the genetic material to the two daughter nuclei may be affected. The same situation will also occur if the chromosomes are broken or damaged by radiation, drugs and chemicals. Under these conditions, the genetic materials that are not included in the nuclei of the daughter cells will then form its own "micronucleus". A MNT is a special toxicological test that is usually employed in screening chemical compounds that are potentially genotoxic. The main objective of the test is to identify those genotoxic agents, which are capable of modifying the structure and segregation of chromosomes, in a specific way that enables the induction of micronuclei in interphase cells. MNT is used to determine carcinogenic agents that are capable of triggering off a specific type of cytogenetic damage, which lead to the formation of micronuclei containing lagging chromosome fragments or whole chromosomes. Recently MNT began to be used in gynecology and will be one of the most important parameter in prediction, prognoses and response to treatment of cancer in the near future.
\end{abstract}

Key Words: Micronucleus tests; uterine cervical neoplasms; early detection of cancer

ÖZET Kanserin önceden teşhisi ve tahmini jinekolojide hayati rol oynar. Bu alandaki çalışmalar, mikronükleus (MN) ve mikronükleus testinin (MNT) kanserin tahmini için kullanılabileceğini göstermektedir. İnsan malignitelerinin yaklaşı \%92'si epitel dokularda oluşur. Eksfoliye hücrelerde yapılan MN deneyleri yenilikçi genotoksisite tekniğidir ve epitelyal karsinojenler konusundaki çalışmalar için umut vaadetmektedir. Mikronükleus genellikle mitozun metafaz/anafaz geçişinde üretilir. Hücre bölünmesi süreci bozulur ise, iki yavru çekirdekte genetik malzemenin paylaşımı etkilenebilir. Aynı durum kromozomlar radyasyon, ilaçlar ve kimyasallar ile kırılır veya hasarlanırsa da ortaya çıkar. Bu koşullar altında, yavru hücre çekirdeklerinde bulunmayan genetik meteryaller daha sonra kendi mikronukleusunu olușturacaktır. Mikronükleus test ise genotoksik olma potansiyeli taşıyan kimyasal bileşenlerin taramasında kullanllan özel toksikolojik bir testtir. Bu testin temel amacı, interfaz hücrelerinde mikronükleus oluşumuna neden olan kromozomların yapı ve ayrışma modifikasyonundan sorumlu genotoksik ajanların tespit edilmesidir. MNT, bütün kromozomun veya kromozom parçalarının bulunduğu mikronükleusun dizilimini irdeleyerek sitogenetik bir hasarı yaratabilecek kanserojen etkenlerin belirlenmesinde kullanılır. Son dönemlerde MN, jinekoloji dalında kullanılmaya başlanmış olup kısa süre içerisinde kanserin teşhisinde, tahmininde ve tedaviye yanıtın belirlenmesinde önemli bir parametre haline gelecektir.

Anahtar Kelimeler: Mikronükleus testleri; uterin servikal tümörler; kanserin erken tespiti doi: 10.5336/gynobstet.2014-41553

Copyright $\odot 2016$ by Türkiye Klinikleri
Turkiye Klinikleri J Gynecol Obst 2016;26(3):152-9 
"M icronucleus" (MN) means a small nucleus. In mammalian cells, micronuclei are usually produced during the metaphase/anaphase transition of mitosis (Figure 1). ${ }^{1,2}$ The nucleus, which contains the genetic materials, is responsible for controlling all the normal cellular functions. Every species of living organisms has constant chromosome number. During cell division, the genetic material replicates and then divides equally between the two daughter cells that are produced. If the process of cell division is disturbed, the sharing of the genetic material to the two daughter nuclei may be affected. The same situation will also occur, if the chromosomes are broken or damaged by radiation, drugs and chemicals (Figure 2). ${ }^{3}$ Under these conditions, the genetic materials that are not included in the nuclei of the daughter cells will then form its own "micronucleus".

The mammalian MNT, involves the inoculation of mammalian specimen with chemical agent, after which the frequency of micronucleated cells is determined after a specified time, and then compared to the untreated control specimen. ${ }^{4}$ Those inoculated mammalian specimen that have a higher frequencies of $\mathrm{MN}$ are expected to experience numerical and/or structural chromosomal damages due to the chemical agent (Figure 3).

Since chromosomal changes are associated with cancer, many researchers have consequently investigated the ability of certain chemical agents, to trigger chromosomal damage. ${ }^{5}$ Chromosomal damages can occur in both the body cells and the germ cells. Thus, it's known to cause grave reproductive defects like; fetal death, infertility, birth defects, etc.

The two main types of MNT are in vivo test and in vitro test. The exact method to use in a particular case is largely determined by the sample organism, the type of cell that is being assayed, the mode action of the chemicals and the objectives of the investigator. In mammals, the in vivo MNT is used to trace the mitotic apparatus of the erythroblasts or the chromosomal damage that is triggered by the test substance, by analyzing either a sample of erythrocytes obtained from the bone

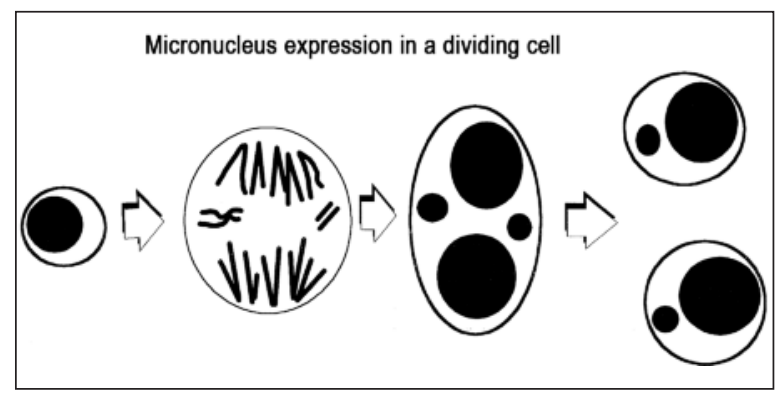

FIGURE 1: The origin of micronuclei from lagging whole chromosomes and acentric chromosome fragments in a dividing cell at anaphase. ${ }^{2}$

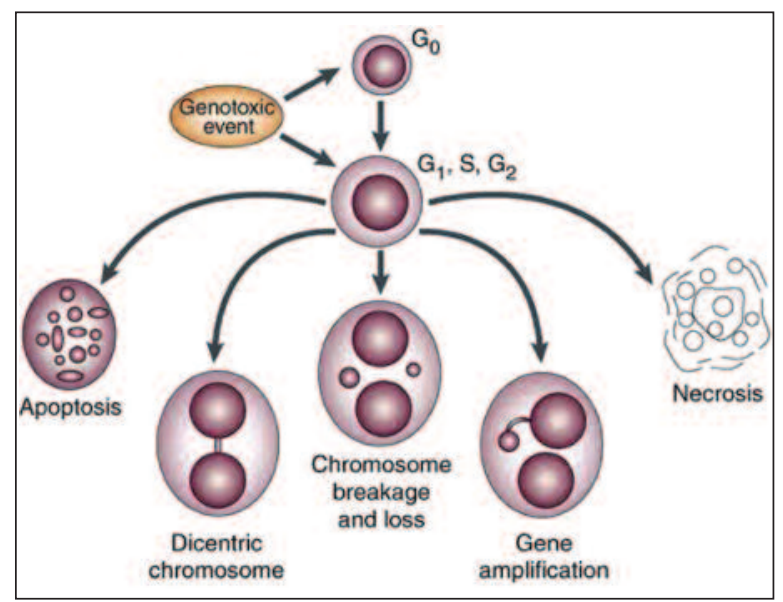

FIGURE 2: The various possible results of cultured cytokinesis-blocked cells following exposure to cytotoxic/genotoxic agents and micronucleus formation. ${ }^{3}$

marrow or peripheral blood cells of the mammals. ${ }^{1,6}$ The absence of nucleus in these cells makes it easier to visualize the micronuclei. An increase in the frequency of micronucleated polychromatic erythrocytes in treated animals is an indication of induced chromosome damage.

Today, the concept is been employed in the identification and predication of cancerous cells. In fact, MNT has now been recognized as one of the most consistent assays for genotoxic carcinogens. Genotoxic carcinogens are those categories of carcinogens that act by damaging the genetic make of the cell.

\section{A TYPICAL METHODOLOGY FOR MICRONUCLEUS TEST}

MNT can be done on cells that are very relevant for human biomonitoring without additional in 
(a)

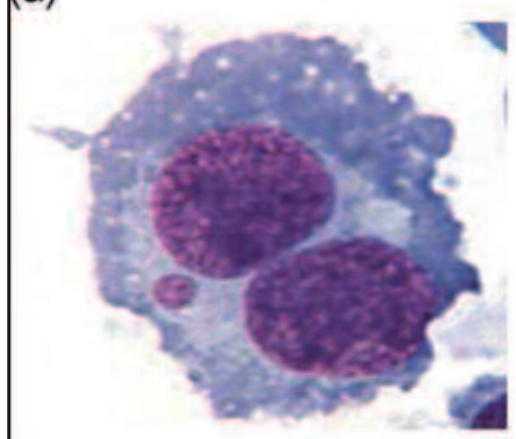

(d)

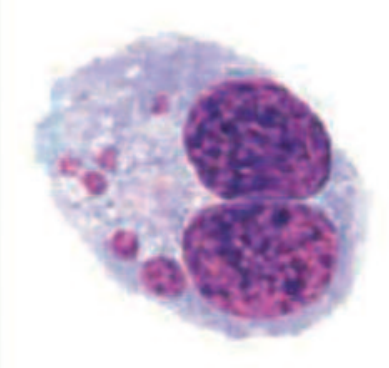

(b)

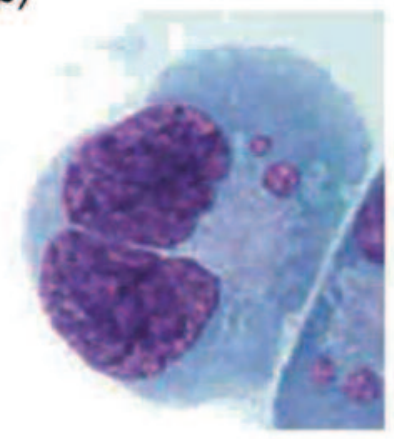

(e)

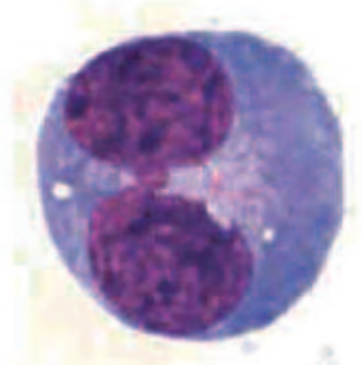

(c)

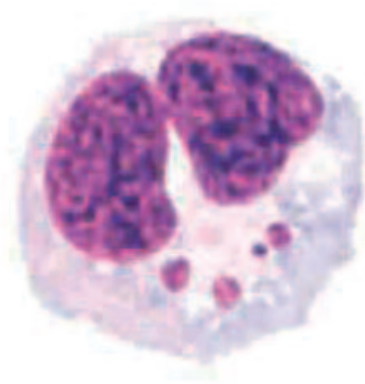

(f)

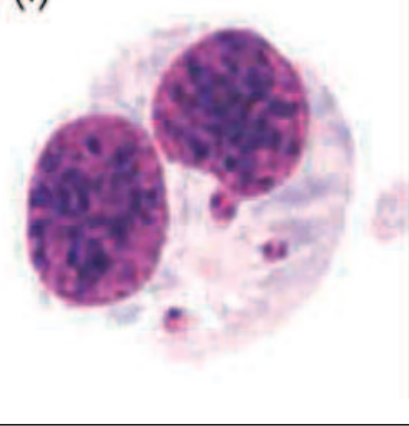

FIGURE 3: (a-f) Photomicrographs of typical binucleated cells (BN) with micronuclei (MN). (e) Illustrates a micronucleus touching both nuclei. ${ }^{4}$

vitro cultivation step. ${ }^{6}$ Some good examples of such cells are lymphocytes, exfoliated epithelial cells and fibroblasts. It's important to note that MN of exfoliated cells are not induced when the cells are at the epithelial surface, but when they are in the basal layer. Micronuclei are formed by chromosomal damage in basal cell of the epithelium. These cells are shed continuously from the surface of the epithelium and are replaced by cell division in the basal cells of the tissue. Cells in these tissues are logical sites for genotoxic damage in humans exposed to carcinogens. ${ }^{7}$

MNT involves exposure of the cell cultures to the chemical agent that is being used as test substances. The exposure may be with or without metabolic activation. After 44 hours of exposure, cytochalasin B should then be added to the cell culture. The main function of this compound is to block cytokinesis (Figure 4).

The cytokinesis-block micronucleus (CBMN) assay is the preferred method for measuring $\mathrm{MNi}$ in cultured human and/or mammalian cells because

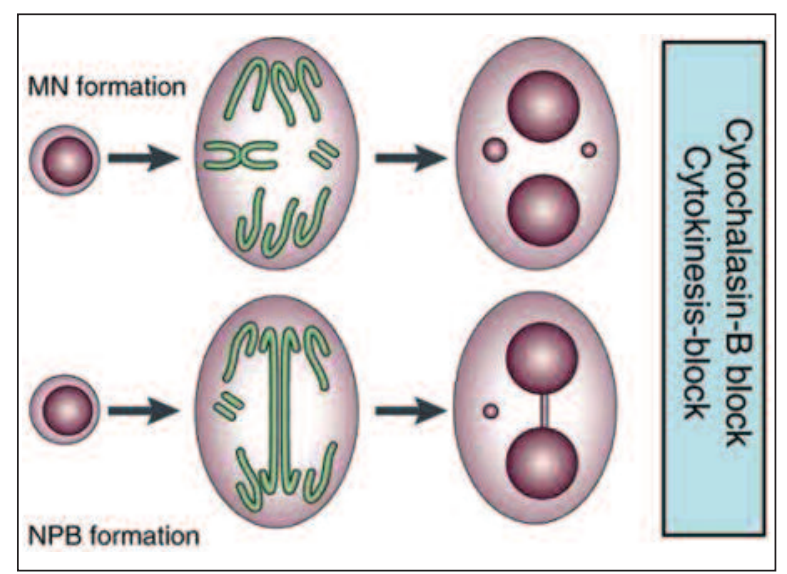

FIGURE 4: MN and nucleoplasmic bridge (NPB), NPB formation in cells undergoing nuclear division. MN originate from either lagging whole chromosomes or acentric chromosome fragments. NPBs originate from dicentric chromosomes that may be caused by misrepair of double strand DNA breaks or telomere end fusions. These events can only be observed in cells completing nuclear division, which are recognized by their BN appearance after cytokinesis blocking with Cytochalsin-B. ${ }^{3}$

scoring is specifically restricted to once-divided $\mathrm{BN}$ cells, which are the cells that can express $\mathrm{MNi}$ (Figure 5). ${ }^{4}$ The culture is then allowed to grow for 

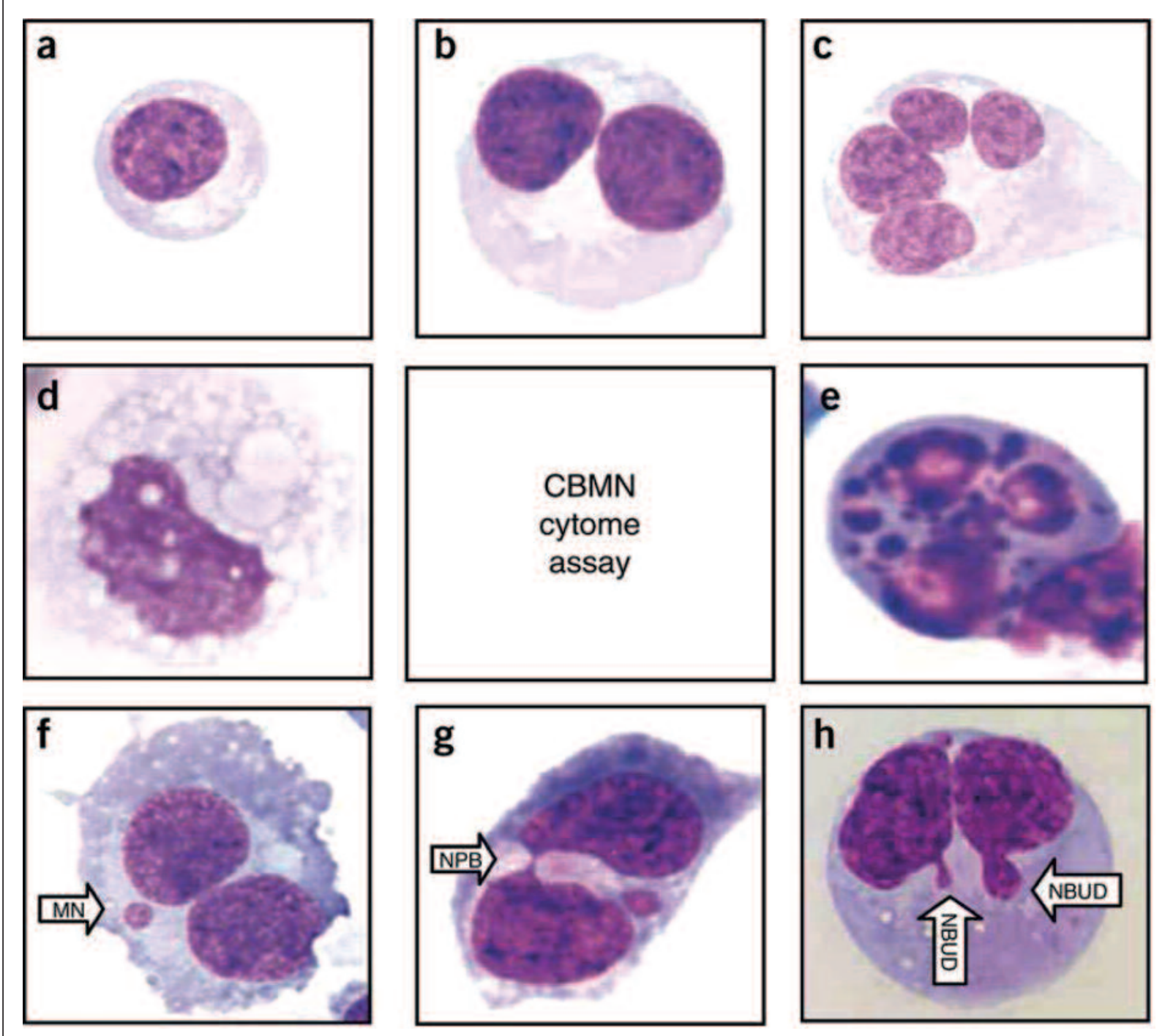

FIGURE 5: Photomicrographs of the cells scored in the CBMN "cytome" assay. (a) Mononucleated cell; (b) BN cell; (c) multinucleated cell; (d) early necrotic cell; (e) late apoptotic cell; (f) BN cell containing one or more MNi; (g) BN containing an NPB (and a MN); (h) BN cell containing nuclear buds (NBUDs). The frequency of BN cells with MNi, NPBs or NBUDs provides a measure of genome damage and/or chromosomal instability. ${ }^{4}$

a period that is adequate to permit chromosomal damage. Chromosomal damage results in the formation of micronuclei in bi- or multinucleated interphase cells. These interphase cells are then collected, stained and analyzed. In terms of exposure concentrations, it's important to have a minimum of 3 analyzable concentrations. For the solubility and cytotoxicity levels, the highest test item concentrations should be $10 \mathrm{mM}, 5 \mathrm{mg} / \mathrm{ml}$ or $5 \mu \mathrm{l} / \mathrm{ml}$. In each experiment, there must also be both negative and positive controls. During the analysis of the result, the investigator must harvest up to 1000 binucleated cells per duplicate cell culture. These should be scored in other to evaluate the frequency of cells with one, two, or more than two micronuclei. In addition to this, all the harvested cells must be grouped into mononucleates, binucleates or multinucleate. The essence of this grouping is to estimate the proliferation index, which can be used as a measure of toxicity. ${ }^{4}$

For the interpretation, a positive result is said to be obtained when the chemical agent triggers a concentration-related increase or increases the number of cells that have micronuclei. A positive result 
indicates the capability of the chemical agent to trigger off chromosomal damage. There is no room for verification once a positive result is obtained. ${ }^{4}$

Approximately $92 \%$ of all of human malignancies occur in epithelial tissues. The MN assay in exfoliated cells is an innovative genotoxicity technique which holds promise for the study of epithelial carcinogens. ${ }^{8}$ The $\mathrm{MN}$ assay is one of the most widely applied short-term tests used in genotoxicity studies and have become one of the most important tests implemented in the evaluation of mutagenicity and carcinogenicity. ${ }^{9}$ Generally, MN of exfoliated epithelial cells assay can be used to investigate genotoxicity in hair follicle cells, oral cavity, corneal epithelial, lung, esophagus, spleen,vagina, urinary bladder, cervix and testis. ${ }^{9-13}$

When the target tissue is epithelial tissue, the exfoliated cell MN assay has advantages over the more widely used MN assay in lymphocytes. The target tissue can be studied directly without stimulation, whereas lymphocytes must first be stimulated. The relationship in epithelial tissues between short-term assay of cytogenetic effects and longterm assay of carcinogenic effects may also be investigated. ${ }^{9}$

\section{GYNECOLOGICAL CANCER}

Gynecologic cancers mainly affect the female reproductive organs about one out of every 60 women. The commonest examples are: endometrial cancer, ovarian cancer and cervical cancer, while the less common ones are: Fallopian tube, vulva, vagina, uterine wall (sarcoma) and placenta (pregnancy tissue: molar pregnancy). ${ }^{14-16}$

The most occurring gynecologic cancer is endometrial cancer. Studies have shown that the disease will affect about $2 \%$ to $3 \%$ of women. It is fourth most common cancer following breast, lung, and colorectal cancers. The main cause of endometrial cancer is over secretion of a female hormone called estrogen, largely caused by obesity and overweight. It can also be triggered by certain medication like prescription for estrogen hormone therapy and tamoxifen (often prescribed for breast cancer treatment). ${ }^{14}$
Despite its relatively low prevalence, ovarian cancer is second gynecologic cancer but the most deadly gynecologic cancers. This is because; the disease is usually detected after it has spread to other parts of the body. Women that experience multiple ovulations are at great risk of developing this cancer. About $10 \%$ of the reported cases of ovarian cancer are genetically acquired. ${ }^{15}$

Cervical cancer mostly affects the lower part of the uterus, just the spot where it joins with the vagina. Cervical cancer used to be the commonest gynecologic cancer across the globe. However, the wide application of Pap tests has made it possible to detect those abnormalities that precede the disease. The main cause of cervical cancer is human papilloma virus (HPV). The human papilloma virus is a sexually transmitted disease. One of its well known symptoms is genital warts. Another common cause of cervical cancer is smoking. ${ }^{16}$

\section{USING MICRONUCLEUS IN GYNECOLOGICAL CANCER PREDICTION}

Despite the new health technologies that have been developed and subsequently implemented for irradiation of cancer patients, pelvic organs morbidity remains a very serious problem. Thus, there is an urgent need to conceptualize a relatively simple, but very reliable method for undertaking routine clinical practice that should serve as a preliminary assessment of normal tissue intrinsic radiosensitivity. ${ }^{17,18}$ One such preliminary test is the MNT, which incidentally can also be used to establish the incidence of the radiation induced micronuclei (MN) in peripheral blood lymphocytes. ${ }^{18}$ Such accomplishment can be employed as an indicator of intrinsic cell radiosensitivity. ${ }^{19}$ Thus, several researchers have conducted in-depth investigation, aimed at determining the most convenient way of using MNT for predicting gynecological cancer.

In an effort to determine the possibility of using MNT for predicting acute radiation morbidity in gynecological cancer patients, Encheva et al. performed MNT on forty patients that are suffering gynecological cancer and 10 healthy women, who 
served as the control group. ${ }^{20}$ The forty women first underwent radical surgery, after which they were subjected to 50 Gy convectional external pelvic radiations together. The MNT was performed before and after the in vitro radiation, at the end of which the average radiation induced frequency of micronuclei per 1000 binucleated cells (MN/1000) was analyzed. Also analyzed were the lymphocytes that contain these 1000 binucleated cells. ${ }^{20}$ At the end of the analysis, it was discovered that two categories of cells have average spontaneous frequencies which are significantly higher in cancer patients compared to the control group $(t=2.46, \mathrm{p}=$ 0.02 and $\mathrm{t}=2.51, \mathrm{p}=0.02) .{ }^{18}$ Despite the absence of an established in vitro MNT applicability for forecasting radiosensitivity in pelvic irradiation, there are much expectations that similar studies will be very instrumental in the individualization of radiotherapy, reduction of adverse events, prophylaxis etc.

Franco dos Reis Campos et al. in their study analyzed the prevalence of MN cells among exfoliated cervical mucosa cells. ${ }^{21}$ The aim was to examine how increased numbers of micronuclei relate to cervical cancer. Cervical mucosa cells were obtained from over 101 patients, with Ayre spatulas. Information regarding the patients' ages, habits (passive or active smoking, alcoholism, inflammatory cytology and cervical intraepithelial neoplasia (CIN) were obtained. This is followed by the conduction of MNTs, after which the samples were observed under 1000x magnification and the frequencies of micronuclei per1,000 epithelial cells per patient sample was determined. At the end of the research, a breakdown of the result obtained are as follows: Comparisons between groups with active $(7.9 \pm 7.8)$ and passive $(7.2 \pm 10.6)$ smoking versus no smoking (3.7 \pm 5.1$)$; with/without alcoholism (7.8 \pm 1.4 and $6.9 \pm 10.1)$; with/without inflammatory cytology $(10.7 \pm 10.5$ and $1.3 \pm 1.7)$; and with CIN I, II and III and no CIN (respectively $4.3 \pm 4.3,10.6 \pm 5.3,22.7 \pm 11.9$ and $1.3 \pm 1.4$ ) found elevated MN prevalence $(\mathrm{P}<0.05)$. This shows that, patients having one or more risk factors for uterine cervical cancers, have greater number of micronuclei in exfoliated uterine cervical cells.
Gandhi and Kaur conducted a comprehensive research on MNT in urothelial cells and uterine smears of cervix cancer patients. ${ }^{22}$ The two tests focused on assessment of cytogenetic damage on patients that are suffering from cervix cancer. This is practically feasible as the genetic end-point screening for micronuclei, enables researchers to measure both chromosome breakage and chromosome loss. Gandhi and his team grouped the MN data under parity levels, age groups, age-at marriage, socio economic status and stage-types of cancer. On comparing the results obtained from the two tissues, it was discovered that, the frequency of MN data was more in urothelial cells except when the variable for age-groups of the patients was compared. This shows that, validated $\mathrm{MN}$ assay can be a reliable tool for predicting cervix cancers. This is because; the method utilizes a non-invasive process of sample collection of sample collection and also score effectively for cytogenetic damage. ${ }^{22}$

Another study conducted by Gandhi and Kaur showed that MNT is particularly more effective in detecting evidences of cervix cancers. ${ }^{23}$ In this case, MNT is conducted in the uterine smears of cervix cancer patients. About 25 women, suffering from cervix cancer and another 25 that had other gynecological complication but not cervix cancer, were used in the study. The data obtained from the preliminary rounds of the study were analyzed by the Student's t-test. The percentage frequency of micronucleated cells found in the 25 cervix cancer patient was $84 \%$, while that of the other 25 women, used as the control individual is just $24 \%$. This shows that MNT is likely to be more effective in predicting cervix cancer, than other gynecological cancers.

Gandhi and Kaur also evaluated the percent frequency of micronucleated cells in different; high parity groups, stage-types, older patients, those with earlier marriages and those belonging to the lower economic status. The test also proved to be a relatively cheap and simple method for evaluating the genetic damage in cervix cancer patients. ${ }^{23}$

Reis Campos et al. investigated the frequency rate of micronuclei in exfoliated cells that were ob- 
tained from the cervical mucosa. ${ }^{23}$ The aim was to determine how increased numbers of micronuclei relates to risk factors of uterine cervical cancer. The results obtained showed that, patients with one or more risk factors have a higher prevalence rate of micronuclei in exfoliated cells than those without any risk factors. ${ }^{21}$

This study results demonstrated a strong association between HPV type infection andMN frequency. MN may comprise an additional criterion for establishing HPV typeinfection and cervical cancer risk. $^{24}$

Similarly Gayathri et al. showed the mean MN scores of invasive cancer and high-grade squamous intraepithelial lesion (HSIL) were significantly high compared to normal, inflammatory, abnormal squamous cells of undetermined significance (ASC-US), abnormal squamous cells cannot exclude HSIL (ASC-H), low-grade squamous intraepithelial lesion (LSIL) group. LSIL showed significant difference with the normal, inflammatory, ASC-US, HSIL and IC, but not with the ASC-H group. ${ }^{25}$ They concluded that MN scoring on the epithelial cells of cervix could be used as a biomarker in cancer screening. This is an easy, simple, reliable, reproducible and objective test which can be performed on routinely stained pap smears. ${ }^{25}$

\section{CONCLUSION}

Analysis of the micronuclei can also be useful in predicting human cancer risks. MNT can be used to determine which carcinogenic agents are capable of triggering off a specific type of cytogenetic damage. The test can be used for gynecological cancer prediction. Especially the population groups with high risk for cervical cancers have been successfully screened with micronuclei test on exfoliated cervical cells. But the use of MNT in other gynecological cancers screening is still insufficient data. More research needs to be done, so as to confirm the reliability of this novel test. In near future MNT might be a perfect biomarker in cancer screening.

\section{REFERENCES}

1. Kissling GE, Dertinger SD, Hayashi M, MacGregor JT. Sensitivity of the erythrocyte micronucleus assay: dependence on number of cells scored and inter-animal variability. Mutat Res 2007;634(1-2):235-40.

2. Fenech $\mathrm{M}$, Holland $\mathrm{N}$, Chang WP, Zeiger $\mathrm{E}$, Bonassi S. The HUman MicroNucleus Project-An international collaborative study on the use of the micronucleus technique for measuring DNA damage in humans. Mutat Res 1999;428(1-2):271-83.

3. Fenech M. Cytokinesis-block micronucleus cytome assay. Nat Protoc 2007;2(5):1084-104.

4. Fenech M, Chang WP, Kirsch-Volders M, Holland N, Bonassi S, Zeiger E; HUman MicronNucleus project. HUMN project: detailed description of the scoring criteria for the cytokinesis-block micronucleus assay using isolated human lymphocyte cultures. Mutat Res 2003;534(1-2):65-75.

5. Kirsch-Volders M, Fenech M. Inclusion of micronuclei in non-divided mononuclear lymphocytes and necrosis/apoptosis may provide a more comprehensive cytokinesis block micronucleus assay for biomonitoring purposes. Mutagenesis 2001;16(1):51-8.
6. Witt KL, Livanos E, Kissling GE, Torous DK, Caspary W, Tice RR, et al. Comparison of flow cytometry- and microscopy-based methods for measuring micronucleated reticulocyte frequencies in rodents treated with nongenotoxic and genotoxic chemicals. Mutat Res 2008;649(1-2):101-13.

7. Rosin MP. The use of the micronucleus test on exfoliated cells to identify anti-clastogenic action in humans: a biological marker for the efficacy of chemopreventive agents. Mutat Res 1992;267(2):265-76.

8. Stich HF, San RH, Rosin MP. Adaptation of the DNA-repair and micronucleus tests to human cell suspensions and exfoliated cells. Ann N Y Acad Sci 1983;407:93-105.

9. Majer BJ, Laky B, Knasmüller S, Kassie F. Use of the micronucleus assay with exfoliated epithelial cells as a biomarker for monitoring individuals at elevated risk of genetic damage and in chemoprevention trials. Mutat Res 2001;489(2-3):147-72.

10. Burgaz S, Cakmak G, Erdem O, Yilmaz M, Karakaya AE. Micronuclei frequencies in exfoliated nasal mucosa cells from pathology and anatomy laboratory workers exposed to formaldehyde. Neoplasma 2001;48(2):144-7.
11. Burgaz S, Karahalil B, Bayrak $P$, Taşkin $L$, Yavuzaslan F, Bökesoy I, et al. Urinary cyclophosphamide excretion and micronuclei frequencies in peripheral lymphocytes and in exfoliated buccal epithelial cells of nurses handling antineoplastics. Mutat Res 1999; 439(1):97-104.

12. Burgaz $S$, Ișcan $A$, Büyükbingöl ZK, Bozkurt $A$, Karakaya AE. Evaluation of micronuclei in exfoliated urothelial cells and urinary thioether excretion of smokers. Mutat Res 1995;335(2): 163-9.

13. Nersesyan AK. Possible role of the micronucleus assay in diagnostics and secondary prevention of cervix cancer: a minireview. Tsitol Genet 2007;41(5):64-6.

14. Dowdy SC, Mariani A, Luarin JR. Uterine cancer. In: Berek JS, ed. Berek and Novak's Gynecology. 15th ed. Philadelphia: Lippincott Williams\&Wilkins; 2012. p.1250303.

15. Berek JS, Longacre TA, Friedlander M. Ovarian, fallopian tube, and peritoneal cancer. In: Berek JS, ed. Berek and Novak's Gynecology. $15^{\text {th }}$ ed. Philadelphia: Lippincott Williams\&Wilkins; 2012. p.1350-427. 
16. Miller $\mathrm{C}$, Elkas JC. Cervical and vaginal cancer. In: Berek JS, ed. Berek and Novak's Gynecology. 15th ed. Philadelphia: Lippincott Williams\&Wilkins; 2012. p.1304-49.

17. West CM, Davidson SE, Elyan SA, Swindell $\mathrm{R}$, Roberts $\mathrm{SA}$, Orton $\mathrm{CJ}$, et al. The intrinsic radiosensitivity of normal and tumour cells. Int J Radiat Biol 1998;73(4):409-13.

18. Biete A, Valduvieco I, Rovirosa A, Farrús B, Casas $\mathrm{F}$, Conill $\mathrm{C}$. Whole abdominal radiotherapy in ovarian cancer. Rep Pract Oncol Radiother 2010;15(2):27-30.

19. Barber JB, Burrill W, Spreadborough AR, Levine $\mathrm{E}$, Warren $\mathrm{C}$, Kiltie AE, et al. Relationship between in vitro chromosomal radiosensitivity of peripheral blood lymphocytes and the expression of normal tissue damage following radiotherapy for breast cancer. Radiother Oncol 2000;55(2):179-86.

20. Encheva E, Deleva S, Hristova R, Hadjidekova V, Hadjieva T. Investigating micronucleus assay applicability for prediction of normal tissue intrinsic radiosensitivity in gynecological cancer patients. Rep Pract Oncol Radiother 2011;17(1):24-31.

21. Reis Campos LM, Luz Dias Fd, Antunes LM, Murta EF. Prevalence of micronuclei in exfoliated uterine cervical cells from patients with risk factors for cervical cancer. Sao Paulo Med J 2008;126(6):323-8.

22. Gandhi G, Sharma P, Kaur A. The micronucleus test in urothelial cells and uterine smears of cervix cancer patients: A comparison. Int J Hum Genet 2003;3(2):121-6.

23. Gandhi $G$, Kaur A. The micronucleus test in uterine epithelial cells of cervix cancer patients. J Hum Ecol 2003;14(6):445-9.

24. Cortés-Gutiérrez EI, Dávila-Rodríguez MI, Vargas-Villarreal J, Hernández-Garza $F$, Cerda-Flores RM. Association between human papilloma virus-type infections with micronuclei frequencies. Prague Med Rep 2010;111(1):35-41.

25. Gayathri B, Kalyani R, Hemalatha A, Vasavi B. Significance of micronucleus in cervical intraepithelial lesions and carcinoma. J Cytol 2012;29(4):236-40. 